OPEN ACCESS

Edited by:

Katja Teerds,

Wageningen University, Netherlands

Reviewed by:

Ewa Rajpert-De Meyts,

Rigshospitalet, Denmark

Alberto Ferlin,

University of Brescia, Italy

*Correspondence:

Julia S. Barthold

Julia.Barthold@nemours.org

Specialty section: This article was submitted to

Reproduction,

a section of the journa

Frontiers in Endocrinology

Received: 30 April 2018

Accepted: 28 June 2018

Published: 23 July 2018

Citation:

Barthold JS and Ivell R (2018) Perspective: A Neuro-Hormonal

Systems Approach to Understanding the Complexity of Cryptorchidism

Susceptibility.

Front. Endocrinol. 9:401.

doi: 10.3389/fendo.2018.00401

\section{Perspective: A Neuro-Hormonal Systems Approach to Understanding the Complexity of Cryptorchidism Susceptibility}

\author{
Julia S. Barthold ${ }^{1 *}$ and Richard Ivell ${ }^{2}$ \\ ${ }^{1}$ Nemours Biomedical Research, Division of Urology, Alfred I. duPont Hospital for Children, Wilmington, DE, United States, \\ ${ }^{2}$ School of Biosciences and School of Veterinary Medicine and Science, University of Nottingham, Sutton Bonington, United \\ Kingdom
}

Nonsyndromic cryptorchidism is a common multifactorial, condition with long-term risks of subfertility and testicular cancer. Revealing the causes of cryptorchidism will likely improve prediction and prevention of adverse outcomes. Herein we provide our current perspective of cryptorchidism complexity in a synthesis of cumulative clinical and translational data generated by ourselves and others. From our recent comparison of genome-wide association study (GWAS) data of cryptorchidism with or without testicular germ cell tumor, we identified RBFOX family genes as candidate susceptibility loci. Notably, RBFOX proteins regulate production of calcitonin gene-related peptide (CGRP), a sensory neuropeptide linked to testicular descent in animal models. We also re-analyzed existing fetal testis transcriptome data from a rat model of inherited cryptorchidism (the LE/orl strain) for enrichment of Leydig cell progenitor genes. The majority are coordinately downregulated, consistent with known reduced testicular testosterone levels in the LE/orl fetus, and similarly suppressed in the gubernaculum. Using qRT-PCR, we found dysregulation of dorsal root ganglia (DRG) sensory transcripts ipsilateral to undescended testes. These data suggest that LE/orl cryptorchidism is associated with altered signaling in possibly related cell types in the testis and gubernaculum as well as DRG. Complementary rat and human studies thus lead us to propose a multi-level, integrated neuro-hormonal model of testicular descent. Variants in genes encoding RBFOX family proteins and/or their transcriptional targets combined with environmental exposures may disrupt this complex pathway to enhance cryptorchidism susceptibility. We believe that a systems approach is necessary to provide further insight into the causes and consequences of cryptorchidism.

Keywords: cryptorchidism, testicular descent, gubernaculum, androgen, insulin-like 3, systems biology

The undescended testis has been the object of continued interest over many years. In April 2018, a search for "cryptorchidism" in PubMed (https://www.ncbi.nlm.nih.gov/pubmed) yielded nearly 10,000 articles spanning almost 100 years. Cryptorchidism has been an area of interest because of its inheritance patterns in domesticated mammals, its high prevalence in man (2-9\% of all newborn boys) and its co-morbidities, including subfertility and testicular cancer. Despite sustained and focused attention, the pathogenesis of cryptorchidism and its associated conditions remain poorly 
understood. Indeed, the more we study the condition, the more complex it seems to become. It stands to reason that better knowledge of the global mechanisms of testicular descent would provide important insight into the causes of cryptorchidism, and would allow us better to predict and prevent this common birth defect and its consequences.

Through our work over the years studying testicular descent and cryptorchidism in animal models and in man, we now propose a consolidated model of testicular descent comprising multilevel integration of neuro-hormonal signaling, and that cryptorchidism results when a combination of genetic and environmental factors target this integrated pathway. Below, we present relevant published and unpublished evidence supporting this perspective.

\section{LEYDIG CELL HORMONES WORK SEPARATELY AND TOGETHER TO BRING ABOUT TESTICULAR DESCENT}

Enlargement and regression/migration of the gubernacular ligament (gubernaculum) connecting the ventral pole of the testis/epididymis to the body wall in the inguinal region are indispensable for testicular descent $(1,2)$. Based on Hutson's hormonal regulation model (3), transabdominal (Phase 1) and transinguinal (Phase 2) descent are distinct, and largely regulated by a non-androgenic hormone, now known to be insulinlike 3 (INSL3), and androgens, respectively. At the same time in most mammals a second ligament, the cranial suspensory ligament (CSL), linking the dorsal pole of the testis to the dorsal surface of the body cavity close to the embryonic kidney, needs to dissolve. Studies of androgen receptor knockout (ARKO) and $t f m$ (testicular feminization) male mice, androgen-exposed female mice, and anti-androgen-exposed rats clearly show that the CSL is regulated by androgens and that its persistence leads to cryptorchidism (4-9). Yet CSL regression is thought to facilitate transabdominal rather than transinguinal, descent. Other inconsistencies exist, complicating efforts to show that distinct hormones regulate distinct phases of descent across species. Remodeling of the CSL may not truly occur, or may be less relevant in human fetuses $(10,11)$. Some human subjects with complete androgen insensitivity syndrome have testes located close to ovarian position (12). Studies in rodents suggest that INSL3 overexpression leads to partial ovarian descent and transinguinal migration of the processus vaginalis, leading to hernia (13), which could be interpreted as an evolutionary relic of a primitive mode of testis excorporation. Similarly, RXFP2, the INSL3 receptor, appears to augment the role of androgens in transinguinal descent (14) and together with AMH may influence gubernacular cell proliferation in culture (15).

Knockout experiments in mice clearly show independent requirements for INSL3/RXFP2 and androgens in testicular descent (16, 17); nevertheless causative mutations in INSL3, RXFP2, AR (androgen receptor) or the Leydig cell regulator NR5A1 (steroidogenic factor-1), are rare in cases of cryptorchidism $(18,19)$. WNT signaling appears to be a downstream target of both INSL3 and androgen in the fetal rat gubernaculum $(20,21)$, and cryptorchidism and/or gubernacular maldevelopment occur in mice with transgenic deletion of WNT pathway genes, such as Sfrp1/Sfrp2, Wnt5a, Ctnnb, or Vangl2 (16, 22-25). Yet none of these genes has been implicated in human cryptorchidism. If INSL3 and androgen are each indispensable for testicular descent, fetal Leydig cell function must play a central role in cryptorchidism susceptibility. This is strongly echoed by studies on the effects of maternal exposure to phthalates in rats where the fetal Leydig cells are seen as primary targets for this endocrine disruptor, leading to a reduction in both INSL3 and testosterone production as well as cryptorchidism (26). Yet the effects of phthalates appear to be species-specific, with humans and mice seemingly more resistant to these inhibitory effects on testicular hormone production $(27,28)$. While detailed studies of Leydig cell function during the prolonged process of testicular descent in human fetuses are unavailable, it is reasonable to assume that genetic and/or environmental factors that alter this function may contribute to cryptorchidism.

\section{THE SENSORY NEUROPEPTIDE CALCITONIN GENE-RELATED PEPTIDE (CGRP) PLAYS A ROLE IN TESTICULAR DESCENT}

A role for CGRP in testicular descent and cryptorchidism is supported by in vitro and in vivo rat studies [reviewed in (29)]. Experiments in newborn rodents showed that transection of the genitofemoral nerve (GFN; which innervates the gubernaculum) causes cryptorchidism, and that CGRP release by the sensory limb of the GFN regulates proliferation and motility of the gubernaculum. Hutson and colleagues found evidence for interaction between CGRP and androgens in rodent models $(30,31)$, and in the absence of clear AR expression in the fetal gubernaculum $(32,33)$ they theorized that androgens indirectly modulate CGRP via effects on surrounding AR+ mammary tissue. However, other data suggest that the fetal gubernaculum does express its own functional AR $(17,21,34-36)$. Clinical data have not shown an association of genetic variants in the CGRP pathway with cryptorchidism (37). However, we recently found a potential role for RBFOX proteins, which regulate production of CGRP, in genetic association analyses of cryptorchidism (see below), which may provide evidence supporting a role for CGRP in humans.

\section{HERITABLE CRYPTORCHIDISM IN THE LE/ORL RAT IS ASSOCIATED WITH MULTI-LEVEL DYSREGULATION OF TESTICULAR DESCENT, AND MULTILOCUS INHERITANCE OF CRYPTORCHIDISM}

The Long Evans-derived LE/orl rat exhibits incompletely penetrant cryptorchidism that is associated with variants in 
at least 2 genes, Syne2 and Ncoa4, which encode ARinteracting proteins (ARIPs) $(38,39)$. As frequently observed in cryptorchid rats exposed prenatally to anti-androgens (4042) and cryptorchid boys, affected LE/orl testes are located in the superficial inguinal pouch, suggesting that this strain is a good model for a common form of clinical cryptorchidism. Testosterone levels and DHT-responsive transcript expression are reduced in LE/orl males, suggesting altered AR signaling (43). Testosterone deficiency alone is likely not sufficient to cause cryptorchidism in this strain, since other work suggests that a more marked reduction in Leydig cell hormone production is required to elicit this effect (44). Interestingly, in a recent reanalysis of transcriptome data (45) based on new information (46), we found that 110 of 315 (35\%) differentially expressed LE/orl fetal testis transcripts map to genes whose expression is enriched in Leydig cell progenitors $\left(n=62 ; p=2 \times 10^{-24}\right)$ or fetal Leydig cells ( $n=48 ; p=4 \times 10^{-11}$; Fisher's exact test using Ingenuity Pathway Analysis/IPA ${ }^{\circledR}$ ). The majority ( 59 of 62 , 95\%) of Leydig cell progenitor-enriched genes are downregulated at E17 in LE/orl as compared to the parent outbred strain
(LE/wt). In addition, 40 of these transcripts are also differentially expressed in fetal gubernaculum, of which 37 (92\%) are similarly downregulated. This evident coordinate gene regulation is lost by E19 (Figure 1A). These data are consistent with work published by the Agoulnik lab, which has shown that a retinoic acid receptor $\beta$ type 2 Cre transgene is expressed in both Leydig cell progenitors and gubernaculum, and that conditional deletion of $A r$ in these cells impairs both testicular descent and fetal Leydig cell survival $(17,47)$. Others have confirmed that Leydig cell progenitors express AR (48), raising the possibility that the mesenchymal progenitors in the testicular interstitium and the gubernaculum may have a common origin, making AR important for both testicular hormone production and response.

LE/orl rats also carry a homozygous insertion within the Prrxl1 (Drg11, Drgx) gene that is inherited together with the Ncoa4 variant. Prrxl1 regulates development of sensory neural circuitry (49) and transgenic deletion in mice leads to loss of CGRP-expressing neurons through apoptosis (50). Using qRT-PCR as described previously (51), we found that Prrxl1 and other sensory transcript levels are altered in the L1-L2

A

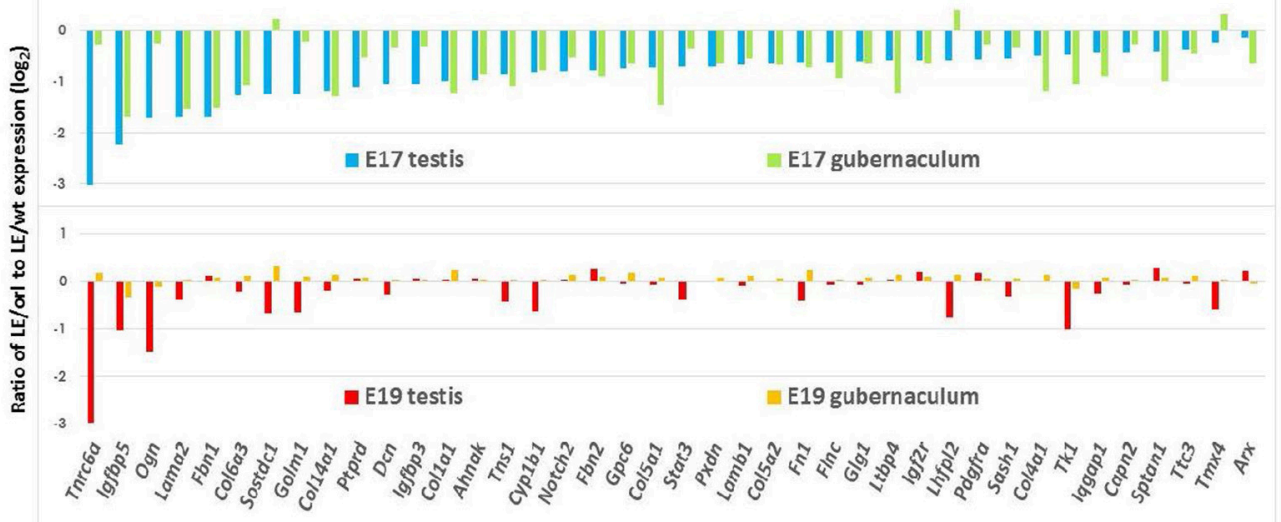

B

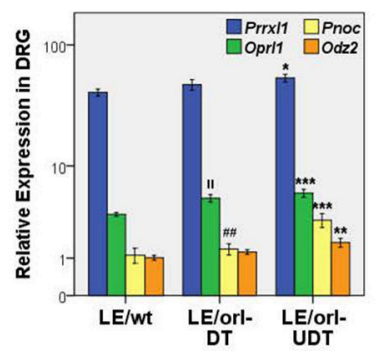

FIGURE 1 | (A) Of 315 differentially expressed genes in LE/orl testis (45), 62 (20\%) are Leydig cell progenitor-specific (46) and expression was reduced in 59 (95\%) of these at E17. Forty of 62 (shown here) are also differentially expressed in LE/orl gubernaculum, and 37 of these (92\%) are also downregulated. By E19, coordinate expression of these genes in these tissues is lost. (B) Expression levels of the sensory transcripts Prrx/1 (paired related homeobox protein-like 1, also known as Drg11 or Drgx), Pnoc (prepronociceptin) and its receptor, Oprl1 (opioid receptor-like 1), and Odz2 (odd oz/ten-m homolog 2, also known as Tenm2) measured by qRT-PCR (logarithmic mean $\pm \mathrm{SEM}$ ) in LE/wt and LE/orl L1-L2 dorsal root ganglia (DRG) ipsilateral to descended (DT) or undescended (UDT) testes. ${ }^{* \star *} p<0.001,{ }^{* *} p<0.01$, ${ }^{*} p<0.05$ vs. LE/wt; $\|_{p}<0.01$ vs. LE/wt; $\# \# p<0.01$ vs. LE/orl-UDT by ANOVA; $n=5-10$ per group, postnatal day 3 DRGs. 
dorsal root ganglia (DRG) of postnatal LE/orl rats, particularly ipsilateral to cryptorchid testes (Figure 1B). These data suggest that altered development of an integrated system comprising Leydig cells, sensory nerves and the gubernaculum together augment the risk of cryptorchidism in LE/orl rat fetuses. Yet even with apparent defects at multiple levels, at least half of all LE/orl testes descend normally. Moreover, we must be cautious when dealing with the potential complexities of geneenvironment interaction, and the anatomical and contextual differences between humans and other mammals. The levels of endocrine disrupting chemicals (EDC) required to cause cryptorchidism in experimental animals are much higher than the typical range of human exposures; yet genetic heterogeneity and the combined effects of multiple environmental influences may put some boys at increased risk. The complexity of the spontaneous LE/orl rat model of cryptorchidism may provide insight into the complexity of cryptorchidism in humans.

\section{THE ETIOLOGY OF HUMAN CRYPTORCHIDISM IS COMPLEX, AND LIKELY ASSOCIATED WITH GENETIC AND ENVIRONMENTAL FACTORS}

Subtle Leydig cell dysfunction, characterized by increased variance in INSL3 levels $(52,53)$ and hence increased risk for susceptibility to other factors, and reduced testosterone/luteinizing hormone $(\mathrm{T} / \mathrm{LH})$ ratio (54-56), may occur in boys with cryptorchidism. It is unclear if these defects are primary or secondary, genetic or environmental. Our genome-wide association study (GWAS) of cryptorchidism identified many suggestive signals, but none surpassed the genome-wide significance threshold (57-59), typical of a polygenic disorder. Pathway analysis of suggestive intragenic signals showed enrichment of genes encoding proteins involved in cytoskeletal functions, including known or predicted ARIPs. Thus, complementary human and rat data suggest that cryptorchidism susceptibility is heterogeneous, multilocus and potentially multifactorial.

\section{RBFOX PROTEINS MAY FUNCTION AS MAJOR REGULATORS OF NEURO-HORMONAL SIGNALING IN TESTICULAR DESCENT AND CONTRIBUTE TO CRYPTORCHIDISM SUSCEPTIBILITY}

Recently, we compared GWAS data from non-syndromic cryptorchidism cases vs. controls (57) and from men with TGCT with or without a history of cryptorchidism vs. controls, and discovered suggestive signals in 19 genes, including RBFOX1 and RBFOX3, paralogs that encode RNA-binding proteins (RBPs) (60). We found that predicted RBFOX targets are strongly enriched among developmental or differentially expressed Leydig cell- and gubernaculum-specific transcripts.

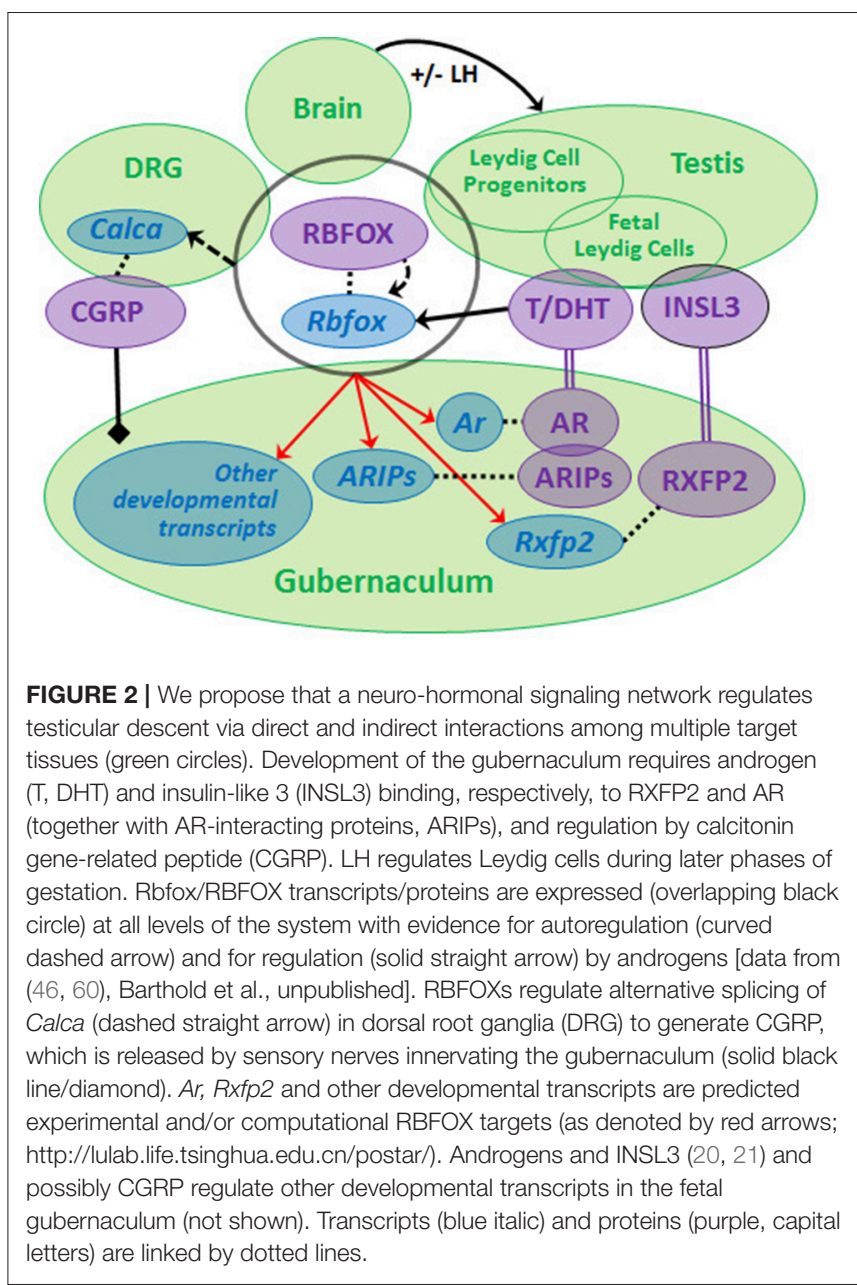

The RBFOX proteins have relevant functions that include sex determination (61) and alternative splicing of Calca to produce CGRP (62). Rbfox 1 and $R b f o x 2$ are expressed in the rat fetal gubernaculum and L1-L2 DRGs, which produce the CGRP needed for gubernacular development, and Rbfox 2 expression is increased by DHT (data not shown). Based on these observations, we hypothesize that a neuro-hormonal RBFOXAR-INSL3-CGRP signaling network regulating testicular descent may exist (Figure 2). We base this model on the neuro-hormonal data from rodent models, and these novel human genetic data suggesting a role for RBFOX genes in cryptorchidism susceptibility. Together, the human and rat data suggest that RBFOX family genes expressed in gubernaculum, testis and DRG (Figure 2) may regulate themselves and each other, playing complex roles in post-transcriptional regulation of CGRP, hormone receptor and/or other developmental molecules. The RBFOX family may therefore connect the hormonal and neural components of this complex network. Genetic variation impacting this network may interact (locally and/or systemically) with adverse effects of environmental endocrine disrupting chemicals (EDCs), augmenting susceptibility to cryptorchidism. 


\section{CONCLUDING SYNTHESIS}

A feature of cryptorchidism which we need to take into account is that its etiology is primarily occurring in the fetus at a time shortly after sex determination when hormonal regulation is largely via local diffusion-based processes, and not by systemic circulationborne events (52). This probably accounts for the preponderance of unilateral, as opposed to bilateral cryptorchidism and the prevalence of ipsilateral rather than general associations between factors. Localized regulatory networks such as we describe here, which may become differentially susceptible through increased variance (statistical "noise") to a range of environmental or possibly epigenetic effects, are unlikely to reveal causality in single elements (genes or hormones) especially when using insensitive and systemic methodological approaches. Moreover, such localized and complex networks are linked to a highly dynamic and irreversible pathway of events, making them increasingly prone to stochastic/serendipitous localized influences, or dosage effects.

The complexity of such pathways (Figure 2) could explain the general failure to identify specific genes or EDCs associated with clinical cryptorchidism. Such data inform our perspective and underscore the need for a broader approach, utilizing

\section{REFERENCES}

1. Heyns CF. The gubernaculum during testicular descent in the human fetus. J. Anat. (1987) 153:93-112.

2. Wensing CJ. The embryology of testicular descent. Horm Res. (1988) 30:14452. doi: 10.1159/000181051

3. Hutson JM. A biphasic model for the hormonal control of testicular descent. Lancet (1985) 2:419-21. doi: 10.1016/S0140-6736(85)92739-4

4. Hutson JM. Testicular feminization: a model for testicular descent in mice and men. J Pediatr Surg. (1986) 21:195-8. doi: 10.1016/S0022-3468(86)80830-2

5. van der Schoot P, Elger W. Androgen-induced prevention of the outgrowth of cranial gonadal suspensory ligaments in fetal rats. J Androl. (1992) 13:534-42.

6. Griffiths AL, Momose Y, Hutson JM. The gubernaculum in adult female, adult male and TFM male mice. Int J Androl. (1993) 16:380-4. doi: 10.1111/j.1365-2605.1993.tb01365.x

7. Lee SM, Hutson JM. Effect of androgens on the cranial suspensory ligament and ovarian position. Anat Rec. (1999) 255:306-15. doi: 10.1002/(SICI)1097-0185(19990701)255:3<306::AID-AR6>3.0.CO;2-B

8. Zimmermann S, Steding G, Emmen JM, Brinkmann AO, Nayernia K, Holstein AF, et al. Targeted disruption of the Insl3 gene causes bilateral cryptorchidism. Mol Endocrinol. (1999) 13:681-91. doi: 10.1210/mend.13.5.0272

9. Perera N, Szarek M, Vannitamby A, Vikraman J, Huan G, Durston A, et al. (2017). An immunohistochemical analysis of the effects of androgen receptor knock out on gubernacular differentiation in the mouse. J Pediatr Surg. doi: 10.1016/j.jpedsurg.2017.11.063. [Epub ahead of print].

10. Barteczko KJ, Jacob MI. The testicular descent in human. Origin, development and fate of the gubernaculum Hunteri, processus vaginalis peritonei, and gonadal ligaments. Adv Anat Embryol Cell Biol. (2000) 156:III-X, 1-98. doi: 10.1007/978-3-642-58353-7

11. Favorito LA, Bernardo FO, Costa SF, Sampaio FJ. Is there a trans-abdominal testicular descent during the second gestational trimester? Study in human fetuses between 13 and 23 weeks post conception. Int Braz J Urol. (2016) 42:558-63. doi: 10.1590/S1677-5538.IBJU.2015.0301

12. Barthold JS, Kumasi-Rivers K, Upadhyay J, Shekarriz B, Imperato-Mcginley J. Testicular position in the androgen insensitivity syndrome: implications for the role of androgens in testicular descent. J Urol. (2000) 164:497-501. doi: 10.1016/S0022-5347(05)67411-3 systems biology and predictive modeling, to increase the likelihood of identifying both the causes and consequences of cryptorchidism.

\section{ETHICS STATEMENT}

This study was carried out in accordance in a facility accredited by the Association for Assessment and Accreditation of Laboratory Animal Care International. The protocol was approved by the Nemours Animal Care and Use Committee (ACUC).

\section{AUTHOR CONTRIBUTIONS}

JB collected and analyzed original data, and JB and RI wrote the manuscript.

\section{FUNDING}

This work was supported by the National Institute of General Medical Sciences (P30GM114736), the Eunice Kennedy Shriver National Institute for Child Health and Human Development (R01HD060769) and Nemours Biomedical Research.

13. Adham IM, Steding G, Thamm T, Bullesbach EE, Schwabe C, Paprotta I, et al. The overexpression of the insl3 in female mice causes descent of the ovaries. Mol Endocrinol. (2002) 16:244-52. doi: 10.1210/mend.16.2. 0772

14. Yuan FP, Li X, Lin J, Schwabe C, Bullesbach EE, Rao CV, et al. The role of RXFP2 in mediating androgen-induced inguinoscrotal testis descent in LH receptor knockout mice. Reproduction (2010) 139:759-69. doi: 10.1530/REP-09-0518

15. Kubota Y, Temelcos C, Bathgate RA, Smith KJ, Scott D, Zhao C, et al. The role of insulin (2002) 3, testosterone, Mullerian inhibiting substance and relaxin in rat gubernacular growth. Mol Hum Reprod. 8:900-5. doi: 10.1093/molehr/8.10.900

16. Kaftanovskaya EM, Feng S, Huang Z, Tan Y, Barbara AM, Kaur S, et al. Suppression of insulin-like3 receptor reveals the role of beta-catenin and Notch signaling in gubernaculum development. Mol Endocrinol. (2011) 25:170-83. doi: 10.1210/me.2010-0330

17. Kaftanovskaya EM, Huang Z, Barbara AM, De Gendt K, Verhoeven G, Gorlov IP, et al. Cryptorchidism in mice with an androgen receptor ablation in gubernaculum testis. Mol Endocrinol. (2012) 26:598-607. doi: 10.1210/me.2011-1283

18. Ferlin A, Zuccarello D, Zuccarello B, Chirico MR, Zanon GF, Foresta C. Genetic alterations associated with cryptorchidism. JAMA (2008) 300:2271-6. doi: 10.1001/jama.2008.668

19. Ferlin A, Rocca MS, Vinanzi C, Ghezzi M, Di Nisio A, Foresta C. Mutational screening of NR5A1 gene encoding steroidogenic factor 1 in cryptorchidism and male factor infertility and functional analysis of seven undescribed mutations. Fertil Steril. (2015) 104:163-9 e161. doi: 10.1016/j.fertnstert.2015.04.017

20. Johnson KJ, Robbins AK, Wang Y, McCahan SM, Chacko JK, Barthold JS Insulin-like 3 exposure of the fetal rat gubernaculum modulates expression of genes involved in neural pathways. Biol Reprod. (2010) 83:774-82. doi: 10.1095/biolreprod.110.085175

21. Barthold JS, Wang Y, Robbins A, Pike J, McDowell E, Johnson KJ, et al. Transcriptome analysis of the dihydrotestosterone-exposed fetal rat gubernaculum identifies common androgen and insulinlike 3 targets. Biol Reprod. (2013) 89:143. doi: 10.1095/biolreprod.113. 112953 
22. Warr N, Siggers P, Bogani D, Brixey R, Pastorelli L, Yates L, et al. Sfrp1 and Sfrp2 are required for normal male sexual development in mice. Dev Biol. (2009) 326:273-84. doi: 10.1016/j.ydbio.2008.11.023

23. Chen N, Harisis GN, Farmer P, Buraundi S, Sourial M, Southwell BR, et al. Gone with the Wnt: the canonical Wnt signaling axis is present and androgen dependent in the rodent gubernaculum. J Pediatr Surg. (2011) 46:2363-9. doi: 10.1016/j.jpedsurg.2011.09.032

24. Chawengsaksophak K, Svingen $\mathrm{T}$, Ng ET, Epp T, Spiller CM, Clark $\mathrm{C}$, et al. Loss of Wnt5a disrupts primordial germ cell migration and male sexual development in mice. Biol Reprod. (2012) 86:1-12. doi: 10.1095/biolreprod.111.095232

25. Harisis GN, Chen N, Farmer PJ, Bodemer D, Li R, Sourial M, et al. Wnt signalling in testicular descent: a candidate mechanism for cryptorchidism in Robinow syndrome. J Pediatr Surg. (2013) 48:1573-7. doi: 10.1016/j.jpedsurg.2012.08.038

26. Wilson VS, Lambright C, Furr J, Ostby J, Wood C, Held G, et al. Phthalate ester-induced gubernacular lesions are associated with reduced insl3 gene expression in the fetal rat testis. Toxicol Lett. (2004) 146:207-15. doi: 10.1016/j.toxlet.2003.09.012

27. Heger NE, Hall SJ, Sandrof MA, McDonnell EV, Hensley JB, McDowell $\mathrm{EN}$, et al. Human fetal testis xenografts are resistant to phthalateinduced endocrine disruption. Environ Health Perspect. (2012) 120:1137-43. doi: 10.1289/ehp.1104711

28. Mitchell RT, Childs AJ, Anderson RA, van den Driesche S, Saunders PT, McKinnell C, et al. Do phthalates affect steroidogenesis by the human fetal testis? Exposure of human fetal testis xenografts to di-n-butyl phthalate. J Clin Endocrinol Metab. (2012) 97:E341-8. doi: 10.1210/jc.2011-2411

29. Hutson JM, Li R, Southwell BR, Newgreen D, Cousinery M. Regulation of testicular descent. Pediatr Surg Int. (2015) 31:317-25. doi: 10.1007/s00383-015-3673-4

30. Goh DW, Momose Y, Middlesworth W, Hutson JM. The relationship among calcitonin gene-related peptide, androgens and gubernacular development in 3 animal models of cryptorchidism. J Urol. (1993) 150:574-6. doi: 10.1016/S0022-5347(17)35554-4

31. Shenker NS, Huynh J, Farmer PJ, Hutson JM. A new role for androgen in testicular descent: permitting gubernacular cell proliferation in response to the neuropeptide, calcitonin gene-related peptide. J Pediatr Surg. (2006) 41:407-12. doi: 10.1016/j.jpedsurg.2005.11.019

32. Heyns CF, Pape VC. Presence of a low capacity androgen receptor in the gubernaculum of the pig fetus. J Urol. (1991) 145:161-7. doi: 10.1016/S0022-5347(17)38282-4

33. Nation TR, Buraundi S, Balic A, Farmer PJ, Newgreen D, Southwell BR, et al. The effect of flutamide on expression of androgen and estrogen receptors in the gubernaculum and surrounding structures during testicular descent. J Pediatr Surg. (2011) 46:2358-62. doi: 10.1016/j.jpedsurg.2011. 09.026

34. Husmann DA, McPhaul MJ. Localization of the androgen receptor in the developing rat gubernaculum. Endocrinology (1991) 128:383-7. doi: 10.1210/endo-128-1-383

35. Bentvelsen FM, George FW. The fetal rat gubernaculum contains higher levels of androgen receptor than does the postnatal gubernaculum. J Urol. (1993) 150:1564-6. doi: 10.1016/S0022-5347(17)35842-1

36. Staub C, Rauch M, Ferriere F, Trepos M, Dorval-Coiffec I, Saunders PT, et al. Expression of estrogen receptor ESR1 and its $46-\mathrm{kDa}$ variant in the gubernaculum testis. Biol Reprod. (2005) 73:703-12. doi: 10.1095/biolreprod.105.042796

37. Zuccarello D, Morini E, Douzgou S, Ferlin A, Pizzuti A, Salpietro DC, et al. Preliminary data suggest that mutations in the CgRP pathway are not involved in human sporadic cryptorchidism. J Endocrinol Invest. (2004) 27:760-4. doi: 10.1007/BF03347519

38. Zhou ZX, He B, Hall SH, Wilson EM, French FS. Domain interactions between coregulator ARA(70) and the androgen receptor (AR). Mol Endocrinol. (2002) 16:287-300. doi: 10.1210/mend.16.2.0765

39. Hsiao JJ, Smits MM, Ng BH, Lee J, Wright ME. Discovery proteomics identifies a molecular link between the coatomer protein complex I and androgen receptor-dependent transcription. J Biol Chem. (2016) 291:1881842. doi: 10.1074/jbc.M116.732313
40. Spencer JR, Torrado T, Sanchez RS, Vaughan, EDJr, Imperato-McGinley J. Effects of flutamide and finasteride on rat testicular descent. Endocrinology (1991) 129:741-8. doi: 10.1210/endo-129-2-741

41. Kassim NM, McDonald SW, Reid O, Bennett NK, Gilmore DP, Payne AP. (1997). The effects of pre- and postnatal exposure to the nonsteroidal antiandrogen flutamide on testis descent and morphology in the Albino Swiss rat. J Anat. 190(Pt. 4), 577-88. doi: 10.1046/j.1469-7580.1997.19040577.x

42. Zakaria O, Shono T, Imajima T, Suita S. Comparative studies of fertility and histologic development of contralateral scrotal testes in two rat models of unilateral cryptorchidism. Pediatr Surg Int. (2000) 16:498-501. doi: $10.1007 /$ s003830000400

43. Barthold JS, Robbins A, Wang Y, Pugarelli J, Mateson A, Anand-Ivell R, et al. Cryptorchidism in the orl rat is associated with muscle patterning defects in the fetal gubernaculum and altered hormonal signaling. Biol Reprod. (2014) 91:41. doi: 10.1095/biolreprod.114.119560

44. Gray, LEJr., Furr J, Tatum-Gibbs KR, Lambright C, Sampson H, Hannas BR, et al. Establishing the "Biological Relevance" of dipentyl phthalate reductions in fetal rat testosterone production and plasma and testis testosterone levels. Toxicol Sci. (2016) 149:178-91. doi: 10.1093/toxsci/kfv224

45. Barthold JS, McCahan SM, Singh AV, Knudsen TB, Si X, Campion L, et al. Altered expression of muscle- and cytoskeleton-related genes in a rat strain with inherited cryptorchidism. J Androl. (2008) 29:352-66. doi: 10.2164/jandrol.107.003970

46. Inoue $\mathrm{M}$, Shima $\mathrm{Y}$, Miyabayashi $\mathrm{K}$, Tokunaga $\mathrm{K}$, Sato $\mathrm{T}$, Baba $\mathrm{T}$, et al. Isolation and characterization of fetal leydig progenitor cells of male mice. Endocrinology (2016) 157:1222-33. doi: 10.1210/en.2015-1773

47. Kaftanovskaya EM, Lopez C, Ferguson L, Myhr C, Agoulnik AI. Genetic ablation of androgen receptor signaling in fetal Leydig cell lineage affects Leydig cell functions in adult testis. FASEB J. (2015) 29:2327-37. doi: 10.1096/fj.14-263632

48. Kilcoyne KR, Smith LB, Atanassova N, Macpherson S, McKinnell C, van den Driesche $\mathrm{S}$, et al. Fetal programming of adult Leydig cell function by androgenic effects on stem/progenitor cells. Proc Natl Acad Sci USA. (2014) 111:E1924-1932. doi: 10.1073/pnas.1320735111

49. Chen ZF, Rebelo S, White F, Malmberg AB, Baba H, Lima D, et al. The paired homeodomain protein DRG11 is required for the projection of cutaneous sensory afferent fibers to the dorsal spinal cord. Neuron (2001) 31:59-73. doi: 10.1016/S0896-6273(01)00341-5

50. Rebelo S, Chen ZF, Anderson DJ, Lima D. Involvement of DRG11 in the development of the primary afferent nociceptive system. Mol Cell Neurosci. (2006) 33:236-46. doi: 10.1016/j.mcn.2006.07.013

51. Barthold JS, Pugarelli J, MacDonald ML, Ren J, Adetunji MO, Polson SW, et al. Polygenic inheritance of cryptorchidism susceptibility in the LE/orl rat. Mol Hum Reprod. (2016) 22:18-34. doi: 10.1093/molehr/gav060

52. Ivell R, Anand-Ivell R, Morley SD. The endocrinology of the fetal testis. In: Simoni M, Huhtaniemi I. editors. Endocrinology of the Testis and Male Reproduction. Berlin: Springer Press (2017). p. 1-28.

53. Anand-Ivell R, Cohen A, Nørgaard-Pedersen B, Jönsson BAG, Bonde JP, Hougaard DM, et al. Amniotic fluid INSL3 measured during the critical time window in human pregnancy relates to cryptorchidism, hypospadias and phthalate load: a large case-control study. Front Physiol. (2018) 9:406. doi: 10.3389/fphys.2018.00406

54. Suomi AM, Main KM, Kaleva M, Schmidt IM, Chellakooty M, Virtanen HE, et al. Hormonal changes in 3-month-old cryptorchid boys. J Clin Endocrinol Metab. (2006) 91:953-8. doi: 10.1210/jc.2004-2318

55. Bay K, Virtanen HE, Hartung S, Ivell R, Main KM, Skakkebaek NE, et al. Insulin-like factor 3 levels in cord blood and serum from children: effects of age, postnatal hypothalamic-pituitary-gonadal axis activation, and cryptorchidism. J Clin Endocrinol Metab. (2007) 92:4020-7. doi: 10.1210/jc.2007-0974

56. Toppari J, Kaleva M, Virtanen HE, Main KM, Skakkebaek NE. Luteinizing hormone in testicular descent. Mol Cell Endocrinol. (2007) 269:34-7. doi: 10.1016/j.mce.2006.10.021

57. Barthold JS, Wang Y, Kolon TF, Kollin C, Nordenskjold A, Olivant Fisher A, et al. Pathway analysis supports association of nonsyndromic cryptorchidism with genetic loci linked to cytoskeleton-dependent functions. Hum Reprod. (2015) 30:2439-51. doi: 10.1093/humrep/dev180 
58. Barthold JS, Wang Y, Kolon TF, Kollin C, Nordenskjold A, Olivant Fisher A, et al. Phenotype specific association of the TGFBR3 locus with nonsyndromic cryptorchidism. J Urol. (2015) 193:1637-45. doi: 10.1016/j.juro.2014.10.097

59. Wang Y, Li J, Kolon TF, Olivant Fisher A, Figueroa TE, BaniHani AH, et al. Genomic copy number variation association study in Caucasian patients with nonsyndromic cryptorchidism. BMC Urol. (2016) 16:62. doi: 10.1186/s12894-016-0180-4

60. Wang Y, Gray DR, Robbins AK, Crowgey EL, Chanock SJ, Greene $\mathrm{MH}$, et al. (2018). Subphenotype meta-analysis of testicular cancer genome-wide association study data suggests a role for RBFOX family genes in cryptorchidism susceptibility. Hum Reprod. 33:967-77. doi: 10.1093/humrep/dey066

61. Hodgkin J, Zellan JD, Albertson DG. Identification of a candidate primary sex determination locus, fox-1, on the $\mathrm{X}$ chromosome of Caenorhabditis elegans. Development (1994) 120:3681-9.
62. Zhou HL, Baraniak AP, Lou H. Role for Fox-1/Fox-2 in mediating the neuronal pathway of calcitonin/calcitonin gene-related peptide alternative RNA processing. Mol Cell Biol. (2007) 27:830-41. doi: 10.1128/MCB. 01015-06

Conflict of Interest Statement: The authors declare that the research was conducted in the absence of any commercial or financial relationships that could be construed as a potential conflict of interest.

Copyright $\odot 2018$ Barthold and Ivell. This is an open-access article distributed under the terms of the Creative Commons Attribution License (CC BY). The use, distribution or reproduction in other forums is permitted, provided the original author(s) and the copyright owner(s) are credited and that the original publication in this journal is cited, in accordance with accepted academic practice. No use, distribution or reproduction is permitted which does not comply with these terms. 